\title{
Analisis Lingkungan Kerja dan Budaya Organisasi Terhadap Kepuasan Kerja Pegawai Bappeda dan Litbang Kabupaten OKU Timur
}

\author{
Wihana \\ Manajemen, STIE Trisna Negara Belitang Sumsel, wihanasuripto@ymail.com
}

\begin{abstract}
ABSTRAK
Tujuan penelitian ini untuk mengetahui pengaruh lingkungan kerja dan budaya organisasi secara bersama-sama terhadap kepuasan kerja pegawai pada Bappeda dan Litbang Kabupaten OKU Timur. Populasi dalam penelitian ini adalah seluruh karyawan pada Bappeda dan Litbang Kabupaten OKU Timur berjumlah 70 orang dan sekaligus sebagai sampel penelitian. Metode pengumpulan data menggunakan kuesioner dan dokumentasi. Teknik analisis yang digunakan dalam penelitian ini adalah regresi linier berganda dengan bantuan software SPSS 22.0 for windows. Hasil penelitian menunjukkan bahwa: 1) Secara bersama-sama terdapat pengaruh yang positif dan signifikan lingkungan kerja dan budaya organisasi terhadap Bappeda dan Litbang Kabupaten OKU Timur. 2) Secara parsial terdapat pengaruh yang positif dan signifikan lingkungan kerja terhadap kepuasan kerja pegawai pada Bappeda dan Litbang Kabupaten OKU Timur. 3) Ssecara parsial terdapat pengaruh yang positif dan signifikan budaya organisasi terhadap kepuasan kerja pegawai pada Bappeda dan Litbang Kabupaten OKU Timur.
\end{abstract}

Kata kunci : Lingkungan Kerja, Budaya Organisasi, Kepuasan Kerja

\section{A. PENDULUAN}

Lingkungan kerja merupakan segala sesuatu yang ada di sekitar para pekerja dan yang dapat mempengaruhi dirinya dalam menjalankan tugas yang dia emban atau yang menjadi tanggung jawabnya. Untuk meningkatkan produktivitasnya maka lingkungan kerja sangat mempengaruhi kinerja karena lingkungan kerja yang baik akan menciptakan kemudahan pelaksanaan tugas. Lingkungan kerja ini sendiri terdiri dari lingkungan kerja fisik dan non fisik yang melekat dengan karyawan sehingga tidak dapat dipisahkan dari usaha pengembangan kinerja karyawan.

Budaya organisasi dapat difungsikan sebagai tuntunan yang mengikat para anggotanya karena dapat diformulasikan secara formal dalam berbagai peraturan dan ketentuan organisasi, maka individuindividu yang ada di dalam organisasi secara tidak langsung akan terikat sehingga dapat membentuk sikap dan perilaku yang sesuai dengan visi dan misi serta strategi organisasi. Proses pembentukan tersebut pada akhirnya akan membantu dalam menghasilkan individu-individu yang cakap dan mempunyai integritas yang tinggi, yang nantinya selain menghasilkan SDM yang berkualitas juga akan menjadi suksenya suatu organisasi.

$$
\text { Budaya organisasi yang }
$$
terbentuk di Bappeda dan Litbang Kabupaten OKU Timur dalam penerapannya belum menjiwai seluruh insan karyawan yang ada dan belum memberikan karakter khas Bappeda dan Litbang Kabupaten OKU Timur yang merupakan suatu perwujudan agar dapat menarik kepercayaan masyarakat. Budaya organisasi yang terbentuk adalah budaya organisasi melalui top-down approach. Pendekatan top-down approach menunjukkan bahwa pimpinan Bappeda dan Litbang Kabupaten OKU Timur mengharuskan setiap karyawan berperilaku dengan pola tertentu, sesuai dengan norma dan nilai-nilai 
organisasi. Misalnya setiap karyawan wajib mematuhi dan menghormati atasannya, berdisiplin dan melaksanakan tugasnya sesuai dengan ketentuan kode etik organisasi. Namun demikian hal tersebut tidak direspon dengan positif oleh sebagian karyawan yang ada di Bappeda dan Litbang Kabupaten OKU Timur tersebut karena masih ada sebagian karyawan yang berperilaku tidak disiplin dalam melakukan pekerjaannya, sulit bekerja sama dengan rekan kerjanya dan kurangnya rasa saling menghormati sesama rekan kerja.

Untuk mendukung perubahan itu diperlukan adanya acuan baku yang diberlakukan oleh suatu organisasi atau perusahaan. Acuan baku tersebut adalah budaya organisasi yang secara sistematis menuntun para karyawan untuk meningkatkan komitmen kerjanya pada organisasi atau perusahaan.

Kepuasan kerja mencerminkan perasaan seseorang terhadap pekerjaannya. Ini nampak dari sikap karyawan terhadap pekerjaan dan segala sesuatu di lingkungan kerjanya. Menurut Handoko (2008) menjadi kewajiban setiap pemimpin perusahaan untuk menciptakan kepuasan kerja bagi para karyawannya, karena kepuasan kerja merupakan faktor yang diyakini dapat mendorong dan mempengaruhi semangat kerja karyawan agar karyawan dapat bekerja dengan baik dan secara langsung akan mempengaruhi prestasi karyawan. Seorang manajer juga dituntut agar memberikan suasana kerja yang baik dan menyenangkan, juga jaminan keselamatan kerja sehingga karyawan akan merasa terpuaskan.

Dari hasil pra riset yang dilakukan peneliti, tingkat ketidakpuasan kerja yang terjadi di Bappeda dan Litbang Kabupaten OKU Timur dapat dilihat dari ketidakhadiran karyawan yang diduga terjadi karena rutinitas pekerjaan mereka sendiri. Permasalahan dalam penelitian ini adalah apakah ada pengaruh yang lingkungan kerja dan budaya organisasi terhadap Kepuasan Kerja Pegawai Pada Bappeda dan Litbang Kabupaten OKU Timur? Tujuan dari penelitian ini ingin membuktikan pengaruh lingkungan kerja dan budaya organisasi terhadap kepuasan kerja pegawai pada Bappeda dan Litbang Kabupaten OKU Timur. Dari uraian di atas, maka peneliti ingin menganalisis lebih lanjut tentang Lingkungan Kerja dan Budaya Organisasi serta pengaruhnya Terhadap Kepuasan Kerja Pegawai Pada Bappeda dan Litbang Kabupaten OKU Timur.

\section{B. KAJIAN TEORI}

1) Lingkungan Kerja

Menurut Sukanto dan Indriyo dalam Khoiriyah (2009) lingkungan kerja adalah segala sesuatu yang ada disekitar pekerja yang dapat mempengaruhi dalam bekerja meliputi mengaturan penerangan, pengontrolan suara gaduh, pengaturan kebersihan tempat kerja dan pengaturan keamanan tempat kerja. Sedangkan Nitisemito dalam Khoiriyah (2009) lingkungan kerja adalah segala sesuatu yang ada disekitar para pekerja dan dapat mempengaruhi dirinya dalam menjalankan tugas yang dibebankan.

Sedarmayanti dalam Wulandari (2011), menyatakan bahwa secara garis besar, jenis lingkungan kerja terbagi menjadi 2 yaitu lingkungan kerja fisik dan lingkungan kerja non fisik. Senada dengan Nitisemito, Robbins dalam Vemmylia (2009:40) mendefinisikan lingkungan kerja adalah segala sesuatu yang ada disekitar para pekerja dan yang dapat mempengaruhi dirinya dalam 
menjalankan tugas-tugas yang dibebankan. Kemudian Rivai dalam Vemmylia (2009) mendefinisikan lingkungan kerja adalah keseluruhan sarana dan prasarana yang ada disekitar karyawan yang sedang melakukan pekerjaan itu sendiri.

Dari beberapa defenisi diatas dapat disimpulkan bahwa lingkungan kerja adalah segala sesuatu yang ada disekitar para pekerja/karyawan yang dapat mempengaruhi kepuasan kerja karywan dalam melaksanakan pekerjaannya sehingga akan diperoleh hasil kerja yang maksimal, dimana dalam lingkungan kerja tersebut terdapat fasilitas kerja yang mendukung karyawan dalam penyelesaian tugas yang bebankan kepada karyawan guna meningkatkan kerja karyawan dalam suatu perusahaan.

\section{2) Budaya Organisasi}

Kata budaya (Culture) sebagai suatu konsep berakar dari kajian atau disiplin ilmu Antropologi ; yang oleh Killman . et. Al (dalam Nimran, 2010) diartikan sebagai Falsafah, ideologi, nila-nilai, anggapan, keyakinan, harapan, sikap dan norma yang dimiliki bersama dan mengikat suatu masyarakat.

Pendapat Robbins (dalam Tika, 2008) semua organsasi mempuyai budaya yang tidak tertulis yang mendefinisikan standar-standar perilaku yang dapat diterima dengan baik maupun tidak untuk para karyawan. Dan proses akan berjalan beberapa bulan, kemudian setelah itu kebanyakan karyawan akan memahami budaya organiasi mereka seperti, bagaimana berpakaian untuk kerja dan lain sebagainya

Sedangkan Alisyahbana (dalam Supartono, 2011) budaya merupakan manifestasi dari cara berfikir, sehingga menurutnya pola kebudayaan itu sangat luas sebab semua tingkah laku dan perbuatan, mencakup di dalamnya perasaan karena perasaan juga merupakan maksud dari pikiran.

Kemudian Peruci dan Hamby (dalam Tampubolon, 2009) mendefisinisikan budaya adalah segala sesuatu yang dilakukan, dipikirkan, dan diciptakan oleh manusia dalam masyarakat, serta termasuk pengakumulasian sejarah dari objek-objek atau perbuatan yang dilakukan sepanjang waktu.

Menurut Davis (dalam Lako, 2010: 29) budaya organisasi merupakan pola keyakinan dan nilainilai organisasi yang dipahami, dijiwai dan dipraktekkan oleh organisasi sehingga pola tersebut memberikan arti tersendiri dan menjadi dasar aturan berperilaku dalam organisasi. Hal yang sama juga diungkapkan oleh Mangkunegara (2008: 113) yang menyatakan bahwa budaya organisasi adalah seperangkat asumsi atau sistem keyakinan, nilai-nilai, dan norma yang dikembangkan dalam organisasi yang dijadikan pedoman tingkah laku bagi anggota-anggotanya untuk mengatasi masalah adaptasi eksternal dan internal.

Dengan demikian dapat disimpulkan bahwa budaya organisasi merupakan pola keyakinan dan nilainilai organisasi yang diyakini dan dijiwai oleh seluruh anggotanya dalam melakukan pekerjaan sebagai cara yang tepat untuk memahami, memikirkan, dan merasakan terhadap masalah-masalah terkait, sehingga akan menjadi sebuah nilai atau aturan di dalam organisasi tersebut.

\section{3) Kepuasan Kerja}

Kepuasan kerja (job satisfaction) karyawan dalam suatu perusahaan tentunya penting untuk diperhatikan oleh jajaran manajemen karena kepuasan kerja karyawan akan menentukan tingkat semangat kerja dari para karyawan itu sendiri. 
Karyawan yang tingkat kepuasannya tinggi tentunya akan lebih bersemangat dalam melaksanakan tugas-tugas yang diembannya dibandingkan dengan karyawan yang tingkat kepuasannya lebih rendah.

Mendurut Hasibuan (2009). kepuasan kerja adalah sikap emosional yang menyenangkan dan mencintai pekerjaanya. Sikap ini tercermin oleh moral kerja, kedisiplinan dan prestasi kerja. Kepuasan kerja dinikmati dalam pekerjaan, luar pekerjaan dan kombinasi dalam dan luar pekerjaan. Sementara itu Rivai, (2007) menyatakan bahwa kepuasan kerja adalah penilaian dari pekerja tentang seberapa jauh pekerjaannya secara keseluruhan memuaskan kebutuhannya. Kepuasan kerja juga sikap umum yang merupakan hasil dari beberapa sikap, khusus terhadap faktor-faktor pekerjaan, penyesuaian diri, dan hubungan sosial individu diluar kerja

Robbins dalam Wulandari (2011) menyatakan bahwa kepuasan kerja adalah sikap umum terhadap pekerjaan seseorang yang menunjukkan perbedaan antara jumlah penghargaan yang diterima pekerja dan jumlah yang mereka yakini seharusnya mereka terima. Senada dengan Robbins, Porter dalam Pradikta (2011) mendefinisikan kepuasan kerja adalah selisih dari sesuatu yang seharusnya ada dengan sesuatu yang sesungguhnya ada.

Dari pendapat-pendapat diatas dapat disimpulkan bahwa kepuasan kerja adalah sikap seseorang terhadap pekerjaan yang menyenangkan dan memcintai pekerjaan serta harapan seseorang akan penghargaan yang diterimanya dari pekerjaan yang dilakukannya.

\section{4) Kerangka Berfikir}

Kerangka berpikir dapat disajikan dengan bagan yang menunjukkan alur pikir peneliti serta keterkaitan antar variabel yang diteliti. Secara ringkas kerangka pemikiran yang mendasari penelitian ini diilustrasikan kedalam bagan berikut ini :

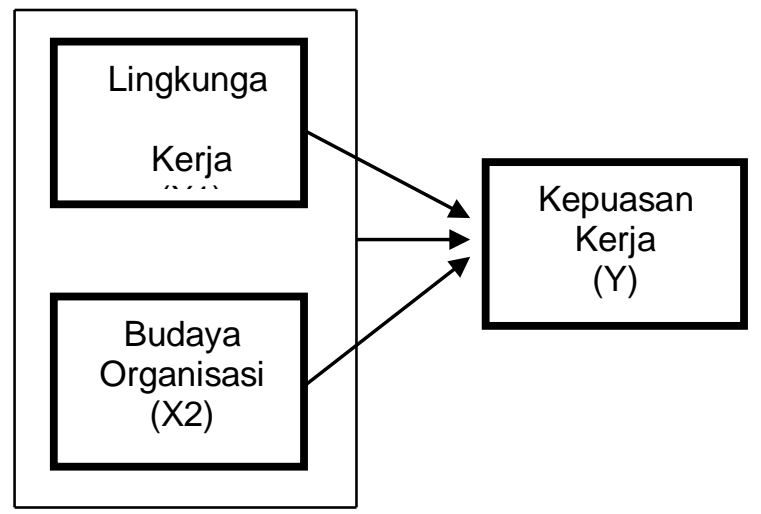

Gambar 1. Kerangka berfikir

\section{PROSEDUR PENELITIAN} Definisi Operasional Variabel

1) Lingkungan Kerja (X1)

Lingkungan kerja adalah segala sesuatu yang ada disekitar para pekerja/karyawan yang dapat mempengaruhi kepuasan kerja karywan dalam melaksanakan pekerjaannya sehingga akan diperoleh hasil kerja yang maksimal, dimana dalam lingkungan kerja tersebut terdapat fasilitas kerja yang mendukung karyawan dalam penyelesaian tugas yang bebankan kepada karyawan guna meningkatkan kerja karyawan dalam suatu perusahaan. Dengan indikator: pewarnaan, penerangan, udara, suara bising, ruang gerak, keamanan dan kebersihan (Sedarmayanti dalam Wulandari, 2011)

\section{2) Budaya Organisasi (X2)}

Budaya organisasi merupakan pola keyakinan dan nilai-nilai organisasi yang diyakini dan dijiwai oleh seluruh anggotanya dalam melakukan pekerjaan sebagai cara yang tepat untuk memahami, memikirkan, dan merasakan terhadap 
masalah-masalah terkait, sehingga akan menjadi sebuah nilai atau aturan di dalam organisasi tersebut. Dengan indikator : inovatif memperhitungkan risiko, memberi perhatian pada setiap masalah secara detail, berorientasi terhadap hasil yang akan dicapai, berorientasi kepada semua kepentingan karyawan, agresif dalam bekerja dan mempertahankan dan menjaga stabilitas kerja (Tampubolon, 2008).

\section{3) Kepuasan Kerja (Y)}

Kepuasan kerja adalah sikap seseorang terhadap pekerjaan yang menyenangkan dan memcintai pekerjaan serta harapan seseorang akan penghargaan yang diterimanya dari pekerjaan yang dilakukannya. Dengan indikatror: gaji, kesempatan untuk promosi, jenis pekerjaan, kebijaksanaan dan prosedur dan kondisi kerja (Griffin dan Moorhead dalam Bangor, 2014).

\section{Populasi dan Sampel}

Dalam penelitan ini yang menjadi populasi adalah seluruh pegawai pada Bappeda dan Litbang Kabupaten OKU Timur berjumlah 70 orang dan sekalgus mengambil keseluruhan dari populasi tersebut untuk dijadikan sampel yaitu berjumlah 70 orang.

\section{E. Metode Pengumpulan Data}

Metode pengumpulan data yang digunakan adalah kuisioner dan dokumentasi. Kusioner adalah sejumlah daftar pertanyaan yang diajukan oleh peneliti untuk mendapatkan informasi yang mendasarkan dari laporan tentang diri sendiri atau pada pengetahuan dan atau keyakinan pribadi subjek atau informasi yang diteliti. Sedangkan dokumentasi ialah data yang berupa dokumen atau catatan tertulis, data yang diperoleh dari dokumentasi merupakan data untuk melengkapi hasil dari wawancara yang telah dilaksanakan/hasil wawancara dapat dipenuhi oleh data tersebut.

\section{Teknik Uji Coba Instrumen}

Dalam uji coba instrumen digunakan uji validitas dan uji reliabilitas Validitas merupakan suatu alat yang digunakan untuk mengukur keshahihan, ketepatan, kecermatan suatu alat ukur dalam melakukan fungsi ukurnya. Suatu tes atau instrumen pengukuran dapat dikatakan mempunyai validitas tinggi apabila alat tersebut dapat mengukur atau memberikan hasil ukur yang sesuai dengan apa yang hendak diukur.

$$
\text { Menurut Priyatno (2010) }
$$

reliabilitas digunakan untuk mengetahui konsistensi alat ukur, apakah alat pengukur yang digunakan dapat diandalkan dan tetap konsisten jika pengukuran tersebut diulang. Uji Reliabilitas yang di gunakan dalam penelitian ini adalah metode Cronbach's Alpha.

\section{$>\quad$ Uji Asumsi}

Sebelum melakukan pengujian hipotesis, terlebih dahulu akan dilakukan pengujian terjadinya penyimpangan terhadap asumsi klasik. Dalam asumsi klasik terdapat beberapa pengujian yang harus dilakukan, yaitu Uji Normalitas, Uji Multikolonieritas dan Uji Heteroskedastisitas.

\section{F. Teknik Analisis Data}

\section{1) Analisis regresi berganda}

Metode analisis regresi berganda dipilih dengan alasan untuk memprediksi hubungan satu variabel dependen dengan dua variabel independen. Dalam penelitian ini variabel independen terdiri dari dua variabel, yaitu lingkungan kerja $\left(X_{1}\right)$ dan budaya organisasi $\left(X_{2}\right)$, sedangkan variabel dependen adalah kepuasan kerja (Y). Model tersebut 
digunakan untuk mendapatkan model regresi yang fit serta meminimumkan gejala heterokedastisitas yang biasanya terjadi pada data cross section.

\section{2) Analisis korelasi dan Determinasi \\ Analisis ini digunakan untuk} mengetahui derajat hubungan antara variabel lingkungan kerja $\left(X_{1}\right)$ dan budaya organisasi $\left(X_{2}\right)$ dengan variabel kepuasan kerja (Y). Dalam analisis korelasi terdapat suatu angka yang disebut dengan Koefisiensi Determinasi yaitu digunakan untuk mengetahui uraian yang dapat diterangkan oleh persamaan regresi serta untuk mengetahui seberapa besar variabel yang dapat diterangkan oleh variabel $X$, yang besarnya adalah kuadrat dari koefisiensi korelasi $\left(r^{2}\right)$. Koefisiensi ini disebut koefisien penentu, karena varians yang terjadi pada variabel dependen dapat dijelaskan melalui varians yang terjadi pada variabel independent.

\section{3) Uji Hipotesis Statistik}

Uji hipotesis statistik adalah pernyataan atau dugaan mengenai satu atau lebih populasi, pengujian hipotesis berhubungan dengan penerimaan atau penolakan suatu hipotesis. Dalam penelitian ini, hipotesis yang diuji adalah uji $F$ digunakan untuk menguji variabelvariabel bebas secara bersama-sama (simultan) terhadap variabel terikat. Dan uji $t$ digunakan untuk menguji signifikansi konstanta dari variabel bebas secara parsial atau individual terhadap variabel terikat.

\section{G. HASIL PENELITIAN}

\section{1) Pengujian Instrumen}

Dari hasil perhitungan uji validitas diperoleh untuk variabel lingkungan kerja dari 10 butir pertanyaan diperoleh nilai $\mathrm{r}_{\text {hitung }}$ semuanya lebih besar dari $r_{\text {tabel. }}$ untuk variabel budaya organisi dari 10 butir pertanyaan diperoleh nilai rhitung semuanya lebih besar dari $r_{\text {tabel. }}$. Dan untuk variabel kepuasan kerja dari 10 butir pertanyaan diperoleh nilai rhitung $_{\text {na }}$ semuanya lebih besar dari $r_{\text {tabel }}$. Dengan demikian dapat disimpulkan bahwa semua butir pernyataan dari ketiga variabel tersebut adalah valid.

Hasil perhitungan untuk uji reliabilitas diperoleh sebagai berikut :

Tabel 1. Rekapitulasi Hasil Uji Reliabilitas

\begin{tabular}{|c|l|c|}
\hline No & \multicolumn{1}{|c|}{ Variabel } & $\begin{array}{c}\text { Cronbach's } \\
\text { Alpa }\end{array}$ \\
\hline 1 & Lingkungan Kerja $\left(\mathrm{X}_{1}\right)$ & 0,813 \\
\hline 2 & Budaya Organisasi $\left(\mathrm{X}_{2}\right)$ & 0,791 \\
\hline 3 & Kepuasan kerja $(\mathrm{Y})$ & 0,824 \\
\hline
\end{tabular}

Sumber : Data primer yang diolah 2018

Dari tabel di atas, maka dapat disimpulkan untuk variabel lingkungan kerja $\left(X_{1}\right)$, budaya organisasi $\left(X_{2}\right)$ dan kepuasan kerja pegawai $(\mathrm{Y})$ memiliki Nilai Cronbach's Alpha $\geq$ Nilai Alpha pada taraf nyata alpha $=5 \%$. Dengan demikian dapat disimpulkan semua item pertanyaan yang ada pada instrumen tersebut dinyatakan reliable dan dapat dijadikan sebagai alat ukur dalam analisis selanjutnya.

\section{2) Pengujian Asumsi Uji Normalitas}

Normal P-P Plot of Regression Standardized Residual

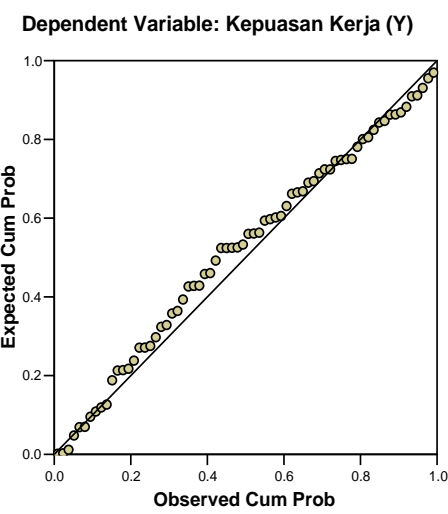

Gambar 2. Normal probability plot 
Berdasarkan gambar di atas, nampak bahwa sebaran (pencaran) data berada di sekitar garis diagonal dan tidak ada yang terpencar jauh dari garis diagonal, sehingga asumsi normalitas dapat dipenuhi.

\section{Uji Multikolinearitas}

Tabel 2. Hasil Uji Multikolinearitas

\begin{tabular}{|c|c|c|}
\hline \multirow{2}{*}{ Variabel } & \multicolumn{2}{|c|}{ Collinearity Statistics } \\
\hline & Tolerance & VIF \\
\hline Lingkungan Kerja $\left(\mathrm{X}_{1}\right)$ & 0,694 & 1,441 \\
\hline Budaya Organisasi $\left(\mathrm{X}_{2}\right)$ & 0,694 & 1,441 \\
\hline
\end{tabular}

Berdasarkan indikator nilai VIF dan tolerance yang dapat dilihat pada tabel di atas, dinyatakan bahwa model regresi dalam penelitian ini terbebas dari persoalan atau problem multikolinearitas, karena nilai VIF dan tolerance masing-masing dibawah dan diatas cut off value yang ditetapkan.

\section{Uji heteroskedastisitas}

Scatterplot

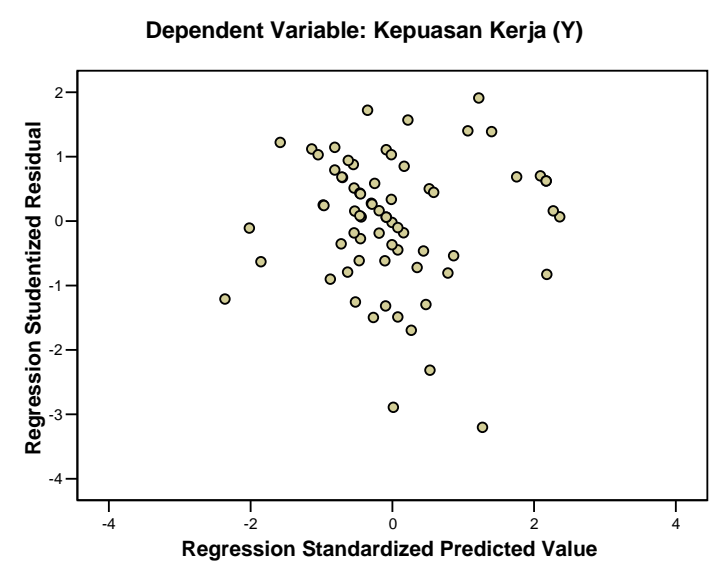

Gambar 3. Grafik Sccaterplot

Berdasarkan Gambar di atas, nampak bahwa noktah-noktah terpencar dengan tidak membentuk pola seperti cerobong asap di sekitar garis diagonal (menyebar lalu menyempit atau sebaliknya), di atas dan di bawah angka 0 pada sumbu $Y$. Dinyatakan bahwa pada model regresi dalam penelitian ini terjadi homoskedastisitas daripada

\section{Analisis Regresi Linier Berganda}

Tabel 3. Analisis Regresi Linier Berganda

Coefficients $^{\mathrm{a}}$

\begin{tabular}{|c|c|c|c|c|c|c|}
\hline \multirow{2}{*}{\multicolumn{2}{|c|}{ Model }} & \multicolumn{2}{|c|}{$\begin{array}{c}\text { Unstandardized } \\
\text { Coefficients }\end{array}$} & \multirow{2}{*}{$\begin{array}{c}\text { Standardized } \\
\text { Coefficients } \\
\text { Beta } \\
\end{array}$} & \multirow[b]{2}{*}{$\mathrm{t}$} & \multirow[b]{2}{*}{ Sig. } \\
\hline & & B & $\begin{array}{l}\text { Std. } \\
\text { Error }\end{array}$ & & & \\
\hline & (Constant) & 1,123 & ,369 & & 3,046 &, 003 \\
\hline & Lingkungan Kerja (X1) & ,260 & ,095 & 284 & 2,733 & ,008 \\
\hline & Budaya Organisasi (X2) & ,492 & 100 &, 509 & 4,907 &, 000 \\
\hline
\end{tabular}

a. Dependent Variable: Kepuasan Kerja $(Y)$

Sumber : Diolah oleh peneliti, 2018

Hasil perhitnugan pada tabel 3 (coefficients) diperoleh nilai persamaan regresi liner berganda sebagai berikut: $Y=1,123+0,260 X_{1}+0,492 X_{2}$
Maka dapat diketahui :

1) Nilai konstanta sebesar 1,123 berarti setiap perubahan atau pengurangan satu satuan skor 
lingkungan kerja dan budaya organisasi akan merubah atau mengurangi skor kepuasan kerja sebesar 1,123.

2) Nilai koefisien regresi $X_{1}$ sebesar 0,260 berarti jika lingkungan kerja naik sebesar satu satuan skor maka kepuasan kerja juga naik sebesar 0,260 dengan ketentuan $\mathrm{X}_{2}$ konstan.

3) Nilai koefisien regresi $X_{2}$ sebesar 0,492 berarti jika budaya organisasi naik sebesar satu satuan skor maka kepuasan kerja juga naik sebesar 0,492 dengan ketentuan $\mathrm{X}_{1}$ konstan.

\section{Koefisien Korelasi (R)}

Tabel 4. Nilai Koefisien Korelasi (R)

Model Summary

\begin{tabular}{|l|r|r|r|r|}
\hline Model & $R$ & $R$ Square & $\begin{array}{c}\text { Adjusted } \\
R \text { Square }\end{array}$ & $\begin{array}{c}\text { Std. Error of } \\
\text { the Es timate }\end{array}$ \\
\hline 1 &, $707^{a}$ &, 499 &, 485 &, 29037 \\
\hline
\end{tabular}

a. Predictors: (Constant), Budaya Organis asi (X2), Lingkungan Kerja (X1)

Sumber : Pengolahan data primer 2018

Dari hasil pengujian diatas diperoleh nilai $R$ sebesar 0,707 berarti pengaruh lingkungan kerja $\left(X_{1}\right)$ dan budaya organisasi $\left(X_{2}\right)$ terhadap kepuasan kerja (Y) kuat. Maksudnya jika ada peningkatan lingkungan kerja $\left(\mathrm{X}_{1}\right)$ dan budaya organisasi $\left(\mathrm{X}_{2}\right)$ maka diikuti juga dengan peningkatan kepuasan kerja (Y). Begitu pula sebaliknya.

\section{$>$ Koefisien Determinasi $\left(\mathbf{R}^{2}\right)$}

Koefisien determinasi $R^{2}$ yang diperoleh adalah sebesar sebesar 0,485 , hal ini berarti lingkungan kerja $\left(\mathrm{X}_{1}\right)$ dan budaya organisasi $\left(\mathrm{X}_{2}\right)$ memberikan sumbangan sebesar 48,5\% terhadap kepuasan kerja pegawai (Y) pada Bappeda dan Litbang Kabupaten OKU Timur sedangkan sisanya $51,5 \%$ dipengaruhi oleh faktor lain yang tidak diteliti.

\section{H. PEMBAHASAN}

1) Pengaruh lingkungan kerja dan budaya organisasi Terhadap Kepuasan Kerja Pegawai
Dari hasil perhitungan uji $F$ diperoleh nilai $F_{\text {hitung }}$ sebesar 33,431. Dengan menggunakan tingkat kepercayaan (confidence interval) 95\% atau alpha $5 \%$ maka diperoleh nilai $F_{\text {tabel }} 3,134$. Dengan membandingkan nilai $F_{\text {hitung }}$ denga $F_{\text {tabel, }}$ maka $F_{\text {hitung }}$ $(33,431)>F_{\text {tabel }}(3,134)$. maka keputusannya adalah menerima $\mathrm{Ha}$ dan Ho ditolak. Hal ini berarti secara bersama-sama variabel lingkungan kerja dan budaya organisasi berpengaruh signifikan terhadap kepuasan kerja pegawai pada Bappeda dan Litbang Kabupaten OKU Timur.

Hasil penelitian ini mendukung penelitian yang dilakukan oleh Widya Parimita, Wendi Hadi Prayuda dan Agung Wahyu Handaru (2013) dengan judul pengaruh lingkungan kerja dan budaya organisasi terhadap kepuasan kerja karyawan pada Bank BTN (Persero) Cabang Bekasi, hasil penelitian menyimpulkan bahwa secara bersama-sama lingkungan kerja dan budaya organisasi memiliki pengaruh yang signifikan terhadap kepuasan kerja karyawan. 


\section{2) Pengaruh Lingkungan Kerja Terhadap Kepuasan Kerja Pegawai}

Hasil pengujian hipotesis variabel lingkungan kerja $\left(X_{1}\right)$ memiliki nilai thitung $(2,733)>$ nilai tabel $(1,996)$, maka keputusannya adalah menerima $\mathrm{Ha}$ dan Ho ditolak. Hal ini berarti variabel lingkungan kerja berpengaruh signifikan terhadap kepuasan kerja pegawai pada Bappeda dan Litbang Kabupaten OKU Timur.

Lingkungan kerja di sekitar karyawan sangat perlu diperhatikan oleh lembaga, sebab merupakan salah satu cara yang dapat ditempuh untuk menjamin agar karyawan dapat melaksankan tugas tanpa mengalami gangguan. Dengan memperhatikan kondisi fisik dari lingkungan kerja karyawan berarti mengurangi rasa jenuh dalam bekerja sehingga dapat melakukan tugasnya secara maksimal dan akhirnya karyawan merasa puas dalam bekerja sehingga meningkatkan kinerja karyawan.

Didalam lingkungan kerja yang baik akan memberikan kenyamanan pribadi dan dapat membangkitkan semangat kerja pegawai sehingga dapat mengerjakan tugas-tugasnya dengan baik.Disamping itu pegawai akan lebih senang dan nyaman dalam bekerja jika fasilitas yang ada dalam keadaan bersih, tidak bising, pertukaran udara yang cukup baik dan peralatan yang memadai serta relative modern. Dengan lingkungan kerja yang baik akan berpengaruh terhadap kepuasan kerja yang dirasakan oleh pegawai.

Hasil penelitian ini mendukung penelitian yang dilakukan oleh Gunawan (2014) dengan judul pengaruh lingkungan kerja terhadap kepuasan kerja karyawan PT. Maton Land Pekanbaru, hasil penelitian menyimpulkan bahwa lingkungan kerja berpengaruh positif dan signifikan terhadap kepuasan kerja.
Lingkungan kerja juga mempengaruhi peningkatan kepuasan kerja pegawai. Dengan adanya lingkungan kerja yang mendukung seperti kebersihan di perusahan membuat suasana kerja yang menyenangkan, hubungan dengan rekan kerja yang harmonis, tersedianya fasilitas kerja yang memadai, penerangan/cahaya yang cukup diruangan, sirkulasi udara yang bersih, tidak adanya bunyi yang tidak dikehendaki/kebisingan, bau tidak sedap, dan terjaminnya keamanan seperti adanya satpam bisa menjaga di lingkungan luar gedung diharapkan menunjang proses dalam bekerja sehingga dapat meningatkan kepuasan kerja.

\section{3) Pengaruh Budaya Organisasi Terhadap Kepuasan Kerja Pegawai}

Hasil pengujian hipotesis untuk bariabel budaya organisasi $\left(\mathrm{X}_{2}\right)$ memiliki nilai thitung $(4,907)>$ nilai $t_{\text {tabel }}$ $(1,996)$, maka keputusannya adalah menerima $\mathrm{Ha}$ dan Ho ditolak. Hal ini berarti variabel budaya organisasi berpengaruh signifikan terhadap kepuasan kerja pegawai pada Bappeda dan Litbang Kabupaten OKU Timur.

Kesuksesan organisasi banyak dipengaruhi oleh berbagai faktor, dimana salah satunya adalah faktor budaya organisasi yang berfungsi sebagai kekuatan, penggerak dalam pencapaian tujuan, dan pembeda antara organisasi yang satu dengan yang lainnya. Apabila sebuah organisasi memiliki anggota atau pegawai yang masih aktif, maka dapat diindikasikan sebagai bukti bahwa organisasi tersebut telah mampu dan sukses dalam memfungsikan budaya organisasi sebagai perekat di dalam kegiatan organisasi setiap harinya serta sebagai pengikat kekompakan antara individu dalam organisasi. 
Budaya organisasi mencerminkan bagaimana melakukan pekerjaan dalam organisasi dan dapat pula mencerminkan budaya kerja. Kesesuaian antara individu dengan budaya baik organisasi maupun budaya setempat sangat penting..

Hasil penelitian ini mendukung penelitian yang dilakukan oleh Budak Bangor (2014) dengan judul pengaruh budaya organisasi terhadap kepuasan kerja pegawai pada Terminal Penumpang Umum Kendal Gorowong Kabupaten Karang Tumaritis, hasil penelitian menyimpulkan bahwa budaya organisasi berpengaruh positif dan signifikan terhadap kepuasan kerja.

Budaya organisasi yang kuat akan membantu organisasi dalam memberikan kepastian kepada seluruh pegawai untuk berkembang bersama, tumbuh dan berkembangnya instansi. Pemahaman tentang budaya organisasi perlu ditanamkan sejak dini kepada pegawai. Bila pada waktu permulaan masuk kerja, mereka masuk ke instansi dengan berbagai karakteristik dan harapan yang berbeda-beda, maka melalui training, orientasi dan penyesuaian diri, pegawai akan menyerap budaya organisasi yang kemudian akan berkembang menjadi budaya kelompok, dan akhirnya diserap sebagai budaya pribadi. Bila proses internalisasi budaya organisasi menjadi budaya pribadi telah berhasil, maka pegawai akan merasa identik dengan instansinya, merasa menyatu dan tidak ada halangan untuk mencapai kinerja yang optimal. Ini adalah kondisi yang saling menguntungkan, baik bagi instansi maupun pegawai.

\section{KESIMPULAN DAN SARAN}

\section{1) Kesimpulan}

Penelitian ini berisikan suatu model yang menguji pengaruh lingkungan kerja dan budaya orgasnisasi terhadap kepuasan kerja pegawai pada Bappeda dan Litbang Kabupaten OKU Timur. Adapun kesimpulan penelitian ini sebagai berikut :

a) Secara bersama-sama lingkungan kerja dan budaya organisasi berpengaruh positif dan signifikan terhadap kepuasan kerja, hal ini berarti bahwa lingkungan kerja dan budaya organisasi yang berlaku pada Bappeda dan Litbang Kabupaten OKU Timur.

b) Secara parsial lingkungan kerja berpengaruh positif dan signifikan terhadap kepuasan kerja pegawai, artinya semakin baik lingkungan kerja pegawai maka semakin baik pula kepuasan kerja pegawai pada Bappeda dan Litbang Kabupaten OKU Timur.

c) Secara parsial juga budaya organisasi berpengaruh positif dan signifikan terhadap kepuasan kerja artinya semakin baik budaya organisasi maka semakin baik pula kepuasan kerja pegawai pada Bappeda dan Litbang Kabupaten OKU Timur.

\section{2) Saran}

a) Bappeda dan Litbang Kabupaten OKU Timur telah menerapkan budaya organisasi yang baik sebagai acuan dalam bekerja. Diharapkan kedepannya, penerapan budaya organisasi lebih ditingktkan lagi agar benarbenar meresap dan dijiwai oleh setiap individu yang ada dalam instansi.

b) Untuk peneliti selanjutnya, diharapkan untuk menambah variabel lain yang dapat dijadikan indikator dalam penelitian lanjutan. Hal ini karena masih adanya variabel-variabel yang belum ditemukan penulis 
yang masih memiliki hubungan yang berkaitan dengan lingkungan kerja, budaya organisasi dan kepuasan kerja pegawai.

\section{DAFTAR PUSTAKA}

Bangor, Budak. 2014. Pengaruh Budaya Organisasi Terhadap Kepuasan Kerja Pegawai Pada Terminal Penumpang Umum Kendal Gorowong Kabupaten Karang Tumaritis. Skripsi. Program Studi Administrasi Pemerintahan Sekolah Tinggiilmu Sosial Dan IImu Politik (Stisip) Syamsul Ulum Karang Tumaritis.

Gunawan. 2014. Pengaruh Lingkungan Kerja Terhadap Kepuasan Kerja Karyawan PT. Maton Land Pekanbaru. Skripsi. Fakultas Ekonomi Dan IImu Sosial Universitas Islam Negeri Sultan Syarif Kasim Riau Pekanbaru.

Handoko, T. Hani. 2008. Manajemen. Edisi Kedua. Penerbit BPFE. Yogyakarta.

Hasibuan, Melayu S. P. 2009. Manajemen Sumber Daya Manusia (MSDM). Bumi Aksara. Jakarta.

Khoiriyah, lilik.2009. Pengaruh upah dan Lingkungan Kerja Terhadap Kinerja Karyawan Pada Cv. Aji Bali Jayawijay Surakarta ${ }_{1} \quad$ Skripsi Sarjana (Tidak dipublikasikan). Surakarta: Fakultas Keguruan Dan IImu Pendidikan. Universitas Muhammadiyah Surakarta.
Lako, Andreas. 2010. Kepemimpinan dan Kinerja Organisasi Isu Teori dan Solnsi. Yogyakarta: Amara Books.

Mangkunegara, Anwar Prabu. 2008. Evaluasi Kinerja SDM. PT Remaja Rosdakarya. Bandung.

Nimran, Umar. 2010. Perilaku Organisasi. Citra Media, Surabaya

Parimita, Widya., Prayuda, Wendi Hadi dan Handaru, Agung Wahyu. 2013. Pengaruh Lingkungan Kerja Dan Budaya Organisasi Terhadap Kepuasan Kerja Karyawan Pada Bank BTN (Persero) Cabang Bekasi. Jurnal Riset Manajemen Sains Indonesia (JRMS). Vol. 4, No. 2, 2013. Fakultas Ekonomi Universitas Negeri Jakarta.

Pradikta, 2011. Pengaruh Budaya Organisasi dan Lingkungan Kerja terhadap Kepuasan Kerja Karyawan pada PT.Global Indonesia Komunikatama Jakarta. Skripsi Universitas Negeri Jakarta

Priyatno, Duwi. 2010. Paham Analisa Statistik Data dengan SPSS. Mediakom Rosdakarya. Yogyakarta

Rivai, Veithzal. 2007. Kepemimpinan dan Prilaku Organisasi. Jakarta: Raja Grafindo Persada.

Supartono, W. 2011. IImu Budaya Dasar. Jakarta: Ghalia Indonesia. 
Tampubolon, Manahan P. 2009. Prilaku Keorganisasian. Jakarta : Ghalia Indonesia.

Tika, Prabunda, H, Moh. 2008. Budaya Organisasi dan Peningkatan Kinerja Perusahaan. PT. Bumi Aksara. Jakarta.

Vemmylia, 2009. Pengaruh Hubungan Interpersonal dan Lingkungan Kerja terhadap Kepuasan Kerja Karyawan PT. PLN cabang Binjai. Skripsi Universitas Sumatera Utara.

Wulandari, 2011. Pengaruh Kompensasi dan Budaya Organisasi terhadap Kepuasan Kerja Karyawan pada Rumah Sakit Duren Sawit Jakarta Timur. Skripsi Universitas Negeri Jakarta. 